11. Онипченко В.Г. Функциональная фитоценология: Синэкология растений: учеб. пособие. М.: КРАСАНД, 2014. 576 с.

12. Левина Р.Е. Репродуктивная биология семенных растений (обзор проблемы). М.: Наука, 1981. $96 \mathrm{c}$.

13. Левина Р.Е. Морфология и экология плодов. Л.: Наука, 1987. 160 с

14. Марков М.В. Популяционная биология растений. М.: Товарищество научных изданий КМК, 2012. 387 c.

15. Булохов А.Д. Экологическая оценка среды методами фитоиндикации. Брянск: Изд-во Брянск. гос. пед. ун-та, 1996. 104 с.

16. Бельгард А.Л. Степное лесоведение. М.: Лесная промышленность, 1971. 336 с.
17. Альбицкая М.А. Основные закономерности формирования травяного покрова в искусственных лесах степной зоны УССР // Искусственные леса степной зоны Украины. Харьков: Изд-во Харьковск. гос. ун-та, 1960. С. 155-208.

18. Матвеев Н.М. Основы степного лесоведения профессора А.Л. Бельгарда и их современная интерпретация: учеб. пособие. Самара: Изд-во «Самарский университет», 2012. 128 с.

19. Горышина Т.К., Антонова И.С., Самойлов Ю.И. Практикум по экологии растений. СПб.: Изд-во СПбГУ, 1992. 140 с.

20. Экологические шкалы и методы анализа экологического разнообразия растений: монография / Л.А. Жукова, Ю.А. Дорогова, Н.В. Турмухаметова [и др.]; под общ. ред. проф. Л.А. Жуковой. ЙошкарОла: Марийск. гос. ун-т, 2010. 368 с.

\title{
BIOECOLOGICAL ANALYSIS OF MOUNTAIN KUZNETSOV VASCULAR PLANTS
}

(C) 2018

Golovlyov Aleksey Alekseevich, doctor of geographical sciences, professor of World Economy Department Samara State University of Economics (Samara, Russian Federation)

Makarova Yulia Vladimirovna, candidate of biological sciences, senior lecturer of Ecology, Botany and Nature Protection Department Prokhorova Nataliya Vladimirovna, doctor of biological sciences, professor of Ecology, Botany and Nature Protection Department Samara National Research University (Samara, Russian Federation)

Abstract. According to the vegetation duration the vascular plants grow on Kuznetsov Mountain form such groups as: summer vegetative species (216 species, 80,9\%), summer-winter-green species (44 species, 16,5\%), evergreen, spring-green, spring-early-summer-green ( 2 species, $0,7 \%$ each) and summer-green or summer-winter-green vascular plants (1 species, 0,4\%). Depending on the pollination ways the entomophillic plants prevail (206 species, $77,1 \%)$, whereas anemophiles (40 species, 15,0\%), self-polinated (3 species, 1,1\%) and species combining entomophilia with self-pollination ( 8 species, $3,0 \%)$, entomophilia with anemophilia ( 1 species, $0,4 \% \%)$ are also presented. According to spreading seeds ways the species form the following descending series: diplohories and polychories $(79$ species, 29,6\%) > ballists, anemochores (55 species, 20,6\% each) > zoochores $(31$ species, 11,6\%) > barochores (29 species, 10,8\%) > automechanochores (8 species, 3,0\%) > hydrochores $(1$ species, $0,4 \%)$. Depending on the ecomorph structure of vegetation, the cenomorphs descending row includes: silvants (75 species, 28,1\%), pratants (48 species, 18,0\%) and ruderants (46 species, 17,2\%), the same for trophomorphs - mesotrophs (154 species, $57,7 \%$ ), among the hygromorphs - mesophytes (98 species, 36,8\%) and xeromesophytes (58 species, 21,7\%), among heliomorphs - heliophytes (152 species, 56,9\%) and scioheliophytes (66 species, 24,7\%), among the thermomorphs - mesotherms (195 species, 73,0\%).

Keywords: flora; vascular plants; seasonal rhythm of development; pheno-rhythmo type; pollination; dissemination; bioecological analysis; ecological-phytocenotic analysis; ecomorph; cenomorph; trophomorph; hygromorph; heliomorph; thermomorph; Mountain Kuznetsov; Sokolii Mountains.

УДК 574.346:574.2:612.11

Статья поступила в редакцию 08.12.2017

\section{ОСОБЕННОСТИ ЭЛЕМЕНТНОГО СОСТАВА КРОВИ ЧЕЛОВЕКА В УСЛОВИЯХ ПРОЖИВАНИЯ НА ТЕРРИТОРИЯХ С РАЗЛИЧНОЙ ДОЗОВОЙ НАГРУЗКОЙ} (C) 2018

Джамбаев Мерей Тлеуканович, аспирант отделения геологии Инженерной школы природных ресурсов

Барановская Наталья Владимировна, доктор биологических наук, профессор отделения геологии Инженерной школы природных ресурсов

Нацииональный исследовательский Томский политехнический университет (г. Томск, Российская Федерация)

Липихина Александра Викторовна, кандидат биологических наук, ведущий научный сотрудник научного отдела

Научно-исследовательский институт радиационной медицины и экологии

(2. Семей, Восточно-Казахстанская область, Республика Казахстан)

Аннотаџия. В данной статье рассматриваются особенности накопления химических элементов в крови населения, проживающего на территориях, прилегающих к бывшему Семипалатинскому испытательному ядерному полигону. Исследуемые территории в результате ранее проведенных радиоэкологических исследований законодательством Республики Казахстан отнесены к разным зонам радиационного риска. В качестве 
контрольной территории выбран населенный пункт Кокпекты, относящийся к минимальной зоне радиационного риска, с дозой облучения от 0,1 до 7 с3в, полученной за весь период испытаний.

Изучение элементного состава крови населения, подверженного различному дозовому облучению на данной территории, проводится впервые. Проведено сравнение концентраций 28 химических элементов, определенных методом инструментального нейтронно-активационного анализа, в крови населения различных зон радиационного риска. Выявлены как территориальные особенности, так и общие характерности накопления химических элементов в крови населения, подверженного различному дозовому облучению.

Рассчитаны суммарные показатели накопления химических элементов в крови человека, характеризующие уровни установленных дозовых нагрузок населения.

Построены биогеохимические ряды накопления химических элементов в крови населения рассматриваемых населенных пунктов, относительно общего среднего по территории. Установлены элементы, вносящие основной вклад в суммарный показатель накопления химических элементов в крови населения исследуемых зон радиационного риска.

В целом показано, что элементный состав крови человека может отражать общую радиоэкологическую обстановку территории.

Ключевые слова: кровь человека; зоны радиационного риска; чрезвычайная зона радиационного риска; максимальная зона радиационного риска; повышенная зона радиационного риска; минимальная зона радиационного риска; дозы облучения; концентрации элементов; биогеохимические ряды накопления элементов; суммарные показатели накопления элементов.

\section{Введение}

Регион, прилегающий к бывшему Семипалатинскому испытательному ядерному полигону, является зоной влияния ядерного техногенеза. С научной точки зрения эта территория представляет интерес для ученых стран, имеющих подобную радиоэкологическую обстановку, для разработки методов оценки радиоэкологической ситуации, а также для изучения медико-биологических эффектов хронического воздействия различных уровней дозовых нагрузок на организм человека $[1 ; 2]$.

Оценка радиоэкологической ситуации рассматриваемой территории и медико-биологических эффектов дозовых нагрузок на организм человека преимущественно производилась расчетным методом путем обобщения и статистического анализа большого массива информации: о возрастно-половом и профессиональном составе населения, о периоде проживания на рассматриваемой территории, о характере питания, здоровья и других показателей [3]. Подобный метод имеет ряд недостатков: во-первых, это требует расположения достаточно длительным временем и человеческими ресурсами, что не всегда представляется возможным; во-вторых, результаты расчетных методов анализа носят вероятностный характер с определенным уровнем математической ошибки и не могут учитывать специфику биогеохимических провинций исследуемой территории, что является важным для точного определения уровня радиохимического загрязнения территории. В данном контексте изучение элементного состава биосубстратов человека, проживающего на исследуемой территории, с применением современного высокоточного лабораторного оборудования резонно имеет свое преимущество. Это становится особенно ценным при условиях оценки радиоэкологической обстановки территорий по следовым показателям радиационного воздействия по истечении длительного времени.

В последнее время для оценки эколого-геохимического состояния окружающей среды активно применяется кровь человека, где предметом исследования, главным образом, является ее элементный состав $[4$, с. 24-30; 5; 6]. Исследования покзали, что элементный состав крови человека может отражать геохимическую специфику среды его проживания [7; 8]. Так, известно, что длительное проживание в ре- гионах воздействия ядерного техногенеза способствует накоплению ряда редкоземельных элементов в крови человека [5]. Причинами изменения элементного состава крови человека могут стать характер его питания, возраст, пол, группа крови, уровень гемоглобина и даже простая смена обстановки [911]. Исследования ученых разных стран показали, что элементный состав крови человека изменяется при изменении состояния его здоровья [12-14]. Механизмы взаимодействия элементного статуса организма и патологических процессов, происходящих в нем, полностью не изучены. Так, у людей с сахарным диабетом 2 типа наблюдалось снижение уровня меди и цинка в крови, при этом неизвестно, способствует ли дисбаланс микроэлементов возникновению сахарного диабета или заболевание является причиной нарушения элементного состава [15].

Целью наших исследований является изучение особенностей элементного состава крови жителей населенных пунктов, характеризующихся как территории с различной дозовой нагрузкой, в результате деятельности бывшего Семипалатинского испытательного ядерного полигона (СИЯП).

\section{Объекты и методы исследования}

Территория, прилегающая к бывшему Семипалатинскому испытательному ядерному полигону, характеризуется как регион с неравномерной дозовой нагрузкой на окружающую среду и на организм человека [16].

Особенности радиоактивного загрязнения от испытаний на полигоне объясняются использованными ядерными материалами и спецификой проведения взрывов. По литературным данным, основной вклад в радиоактивное загрязнение территории, прилегающей к СИЯП, внесли наземные испытания, когда высокотемпературный шар взрыва соприкасается с поверхностью земли и активирует огромное количество частиц грунта. Перенос радиактивных облаков с воздушными потоками в различных направлениях и постепенное осаждение способствовали неравномерному радиоактивному загрязнению прилегающей территории и формированию различных дозовых нагрузок на население [16]. На рисунке 1 представлены основные направления выноса радиоактивных загрязнителей за границы территории СИЯП. 
Джамбаев М.Т., Барановская Н.В., Липихина А.В.

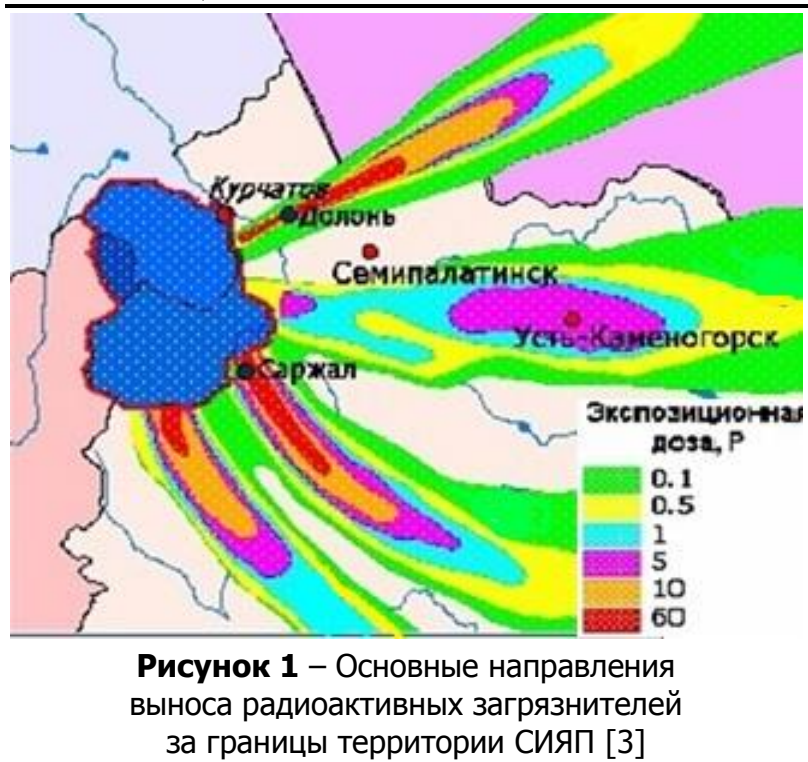

На основании всех ранее проведенных исследований радиоэкологической ситуации территории в 1992 году Правительство Республики Казахстан приняло Закон «О социальной защите граждан, пострадавших вследствие ядерных испытаний на Семипа- латинском испытательном ядерном полигоне». В соответствии с этим законом территории, подвергшиеся влиянию ядерных испытаний на Семипалатинском полигоне, были отнесены к разным зонам радиационного риска (3.P.Р.) [17].

На рисунке 2 показаны географические места расположения населенных пунктов, вошедших в наши исследования, в соответствии установленным зонам радиационного риска.

В таблице 1 представлены уровни коллективных дозовых нагрузок населения исследуемых территорий. Фоновой территорией принят населенный пункт Кокпекты, который отнесен к минимальной зоне радиационного риска, с дозовой нагрузкой от 0,1 до 7 с3в (таблица 1).

Для анализа у каждого респондента отбиралось по 5 мл крови. В каждом исследуемом населенном пункте было отобрано от 5 до 10 проб. Основным критерием при выборе респондентов был факт проживания на исследуемой территории не менее 10 лет. Также было обращено внимание на отсутствие хронических заболеваний у респондентов. В результате было отобрано 60 проб крови. Кровь отбиралась только с информационного согласия респондентов.

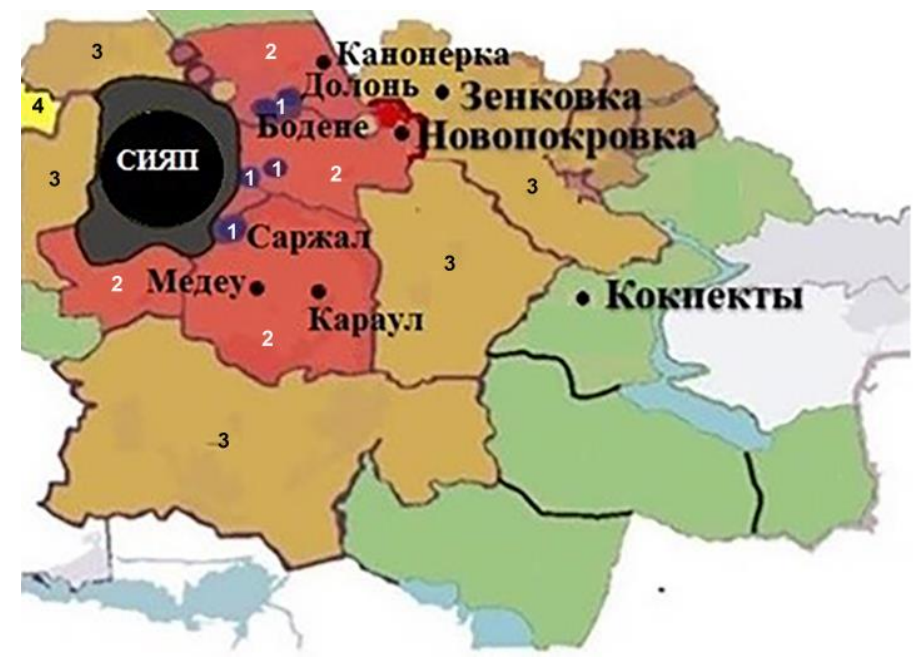

чрезвычайная зона P.P.

максимальная зона Р.P.

повышенная зона Р.P.

территория с льготным социально-экономическим статусом

Рисунок 2 - Расположение исследуемых населенных пунктов в соответствии зонам радиационного риска

Таблица 1 - Уровни дозовых нагрузок на население в исследуемых зонах радиационного риска [3]

\begin{tabular}{|c|c|c|c|}
\hline № & $\begin{array}{c}\text { Исследуемый } \\
\text { населенный } \\
\text { пункт }\end{array}$ & $\begin{array}{c}\text { Зоны } \\
\text { радиацион- } \\
\text { ного } \\
\text { риска }\end{array}$ & $\begin{array}{c}\text { Доза } \\
\text { воздействия } \\
\text { на население } \\
\text { за весь период } \\
\text { испытаний }\end{array}$ \\
\hline 1 & Саржал & \multirow{3}{*}{$\begin{array}{l}\text { Чрезвычай- } \\
\text { ная зона P.P. }\end{array}$} & \multirow{3}{*}{ свыше 100 сЗв } \\
\hline 2 & Бодене & & \\
\hline 3 & Долонь & & \\
\hline 4 & Караул & \multirow{4}{*}{$\begin{array}{l}\text { Максималь- } \\
\text { ная зона Р.P. }\end{array}$} & \multirow{4}{*}{$\begin{array}{c}\text { от } 35 \\
\text { до } 100 \text { с3в }\end{array}$} \\
\hline 5 & Медеу & & \\
\hline 6 & Канонерка & & \\
\hline 7 & Новопокровка & & \\
\hline 8 & Зенковка & $\begin{array}{l}\text { Повышенная } \\
\text { зона Р.Р. }\end{array}$ & от 7 до 35 с3в \\
\hline 9 & Кокпекты & $\begin{array}{l}\text { Минималь- } \\
\text { ная зона Р.Р. }\end{array}$ & от 0,1 до 7 сЗв \\
\hline
\end{tabular}

Для определения элементного состава крови был применен инструментальный нейтронно-активацион- ный анализ (ИНАА), являющийся одним из самых оптимальных современных методов для анализа крови человека $[18 ; 19]$. Анализ проводился на исследовательском ядерном реакторе ИРТ-Т в лаборатории ядерно-геохимических методов исследования кафедры геоэкологии и геохимии Томского политехнического университета (аналитик: с.н.с. А.Ф. Судыко). Накопление и обработка аналитических данных проводились на персональных компьютерах в электронных таблицах «Excel» и с использованием программы «Statistika.10».

\section{Результаты и обсуждение}

В результате проведенного инструментального нейтронно-активационного анализа в крови жителей исследуемых населенных пунктов, были измерены концентрации 28 химических элементов: $\mathrm{Na}, \mathrm{Ca}, \mathrm{Sc}$, $\mathrm{Cr}, \mathrm{Fe}, \mathrm{Co}, \mathrm{Zn}, \mathrm{As}, \mathrm{Br}, \mathrm{Rb}, \mathrm{Sr}, \mathrm{Ag}, \mathrm{Sb}, \mathrm{Cs}, \mathrm{Ba}, \mathrm{La}, \mathrm{Ce}$, $\mathrm{Nd}, \mathrm{Sm}, \mathrm{Eu}, \mathrm{Tb}, \mathrm{Yb}, \mathrm{Lu}, \mathrm{Hf}, \mathrm{Ta}, \mathrm{Au}, \mathrm{Th}, \mathrm{U} . \mathrm{B}$ таблице 2 приведены основные математические параметры концентраций химических элементов в крови населения различных зон радиационного риска. 
Джамбаев М.Т., Барановская Н.В., Липихина А.В.

Особенности элементного состава крови человека в условиях проживания..

03.02.00 - общая биология

Таблица 2 - Основные математические параметры содержания химических элементов в крови населения, проживающего в различных зонах радиационного риска

\begin{tabular}{|c|c|c|c|c|}
\hline Х.э. & $\begin{array}{c}\text { Чрезвычайная зона } \\
\text { Р.P. }(\mathrm{N}=15)\end{array}$ & $\begin{array}{c}\text { Максимальная зона } \\
\text { P.P. }(\mathrm{N}=25)\end{array}$ & $\begin{array}{c}\text { Повышенная зона } \\
\text { P.P. }(\mathrm{N}=10)\end{array}$ & $\begin{array}{l}\text { Минимальная зона } \\
\text { P.P. }(\mathrm{N}=10)\end{array}$ \\
\hline \multirow{2}{*}{$\mathrm{Na}$} & $* 8120 \pm 305$ & $* 6664 \pm 320$ & $* 5870 \pm 395$ & $4150 \pm 327$ \\
\hline & $6683-10565$ & $\overline{4367-9840}$ & $4500-8500$ & $\overline{2300-5300}$ \\
\hline \multirow{2}{*}{$\mathrm{Ca}$} & $* 243 \pm 29$ & $155 \pm 20$ & $* 502 \pm 135$ & $134 \pm 29$ \\
\hline & $\overline{73-418}$ & $\overline{20-352}$ & $\overline{140-1243}$ & $\overline{20-310}$ \\
\hline \multirow{2}{*}{ Sc } & $0,002 \pm 0,001$ & $0,002 \pm 0,001$ & $0,001 \pm 0,0004$ & $0,002 \pm 0,0005$ \\
\hline & $\overline{0,0003-0,01}$ & $\overline{0,0002-0,01}$ & $\overline{0,0002-0,004}$ & $\overline{0,0002-0,01}$ \\
\hline \multirow{2}{*}{$\mathrm{Cr}$} & $* 2,0 \pm 1,1$ & $0,3 \pm 0,06$ & $0,2 \pm 0,01$ & \multirow{2}{*}{ н.П.о. } \\
\hline & $\overline{0,03-17}$ & $\overline{0,2-1,7}$ & $\overline{0,2-0,3}$ & \\
\hline \multirow{2}{*}{$\mathrm{Fe}$} & $* 1840 \pm 81$ & $* 1942 \pm 106$ & $2040 \pm 67$ & $2190 \pm 48$ \\
\hline & $\overline{1175-2236}$ & $\overline{500-3328}$ & $\overline{1700-2300}$ & $\overline{2000-2400}$ \\
\hline \multirow{2}{*}{ Co } & $* 0,2 \pm 0,02$ & $0,1 \pm 0,05$ & $* 0,2 \pm 0,04$ & $0,04 \pm 0,01$ \\
\hline & $\overline{0,03-0,4}$ & $\overline{0,002-1,3}$ & $\overline{0,1-0,4}$ & $\overline{0,004-0,1}$ \\
\hline \multirow{2}{*}{$Z n$} & $22 \pm 1,5$ & $24 \pm 1,9$ & $25 \pm 1,8$ & $23 \pm 2,5$ \\
\hline & $\overline{7,4-28}$ & $\overline{11-49}$ & $\overline{15-30}$ & $\overline{4,1-31}$ \\
\hline \multirow{2}{*}{ As } & $0,4 \pm 0,1$ & $0,3 \pm 0,04$ & \multirow{2}{*}{ н.П.о. } & $0,3 \pm 0,07$ \\
\hline & $\overline{0,1-0,5}$ & $\overline{0,01-0,5}$ & & $\overline{0,01-0,5}$ \\
\hline \multirow{2}{*}{$B r$} & $* 8,2 \pm 0,8$ & $* 6,7 \pm 0,6$ & $* 5,0 \pm 0,4$ & $3,2 \pm 0,2$ \\
\hline & $3,6-17$ & $\overline{1,8-14}$ & $\overline{3,8-7,8}$ & $\overline{2,4-4,2}$ \\
\hline \multirow{2}{*}{$R b$} & $6,3 \pm 0,5$ & $5,7 \pm 0,3$ & $5,0 \pm 0,4$ & $6,3 \pm 0,4$ \\
\hline & $\overline{3,5-11}$ & $\overline{2,9-9,3}$ & $\overline{2,1-6,1}$ & $\overline{4,1-9,0}$ \\
\hline \multirow{2}{*}{$S r$} & \multirow{2}{*}{ н.П.о. } & $0,8 \pm 0,2$ & $3,3 \pm 1,2$ & $0,9 \pm 0,4$ \\
\hline & & $\overline{0,5-6,5}$ & $\overline{0,5-8,3}$ & $\overline{0,5-4,5}$ \\
\hline \multirow{2}{*}{$A g$} & $0,03 \pm 0,01$ & $0,04 \pm 0,01$ & $0,03 \pm 0,005$ & $0,05 \pm 0,01$ \\
\hline & $\overline{0,01-0,1}$ & $\overline{0,02-0,1}$ & $\overline{0,01-0,1}$ & $\overline{0,03-0,1}$ \\
\hline \multirow{2}{*}{$S b$} & $0,02 \pm 0,01$ & $0,01 \pm 0,002$ & $0,03 \pm 0,02$ & $0,01 \pm 0,003$ \\
\hline & $\overline{0,003-0,01}$ & $\overline{0,01-0,06}$ & $\overline{0,01-0,2}$ & $\overline{0,005-0,04}$ \\
\hline \multirow{2}{*}{$C s$} & $* 0,01 \pm 0,002$ & $* 0,01 \pm 0,001$ & $0,004 \pm 0,001$ & $0,003 \pm 0,002$ \\
\hline & $\overline{0,001-0,03}$ & $\overline{0,0004-0,02}$ & $\overline{0,001-0,01}$ & $\overline{0,001-0,02}$ \\
\hline \multirow{2}{*}{$B a$} & $1,6 \pm 0,3$ & $1,7 \pm 0,6$ & $2,1 \pm 1,1$ & $0,8 \pm 0,3$ \\
\hline & $\overline{0,2-4,0}$ & $\overline{0,2-14}$ & $\overline{0,5-12}$ & $\overline{0,1-2,4}$ \\
\hline & $* 0,4 \pm 0,3$ & $0,03 \pm 0,01$ & $0,02 \pm 0,002$ & \\
\hline La & $\overline{0,01-3,9}$ & $\overline{0,02-0,2}$ & $\overline{0,01-0,03}$ & Н.П.О. \\
\hline & $* 1,2 \pm 0,8$ & $* 0,1 \pm 0,02$ & $0,02 \pm 0,01$ & $0,01 \pm 0,005$ \\
\hline Ce & $0,03-12$ & $0,003-0,7$ & $\overline{0,001-0,1}$ & $\overline{0,003-0,1}$ \\
\hline$N d$ & $* 0,7 \pm 0,4$ & $0,2 \pm 0,02$ & $0,1 \pm 0,003$ & $0,1 \pm 0,05$ \\
\hline$N d$ & $\overline{0,1-6,2}$ & $\overline{0,01-0,3}$ & $\overline{0,01-0,04}$ & $\overline{0,05-0,7}$ \\
\hline$S_{m}$ & $* 0,1 \pm 0,06$ & $0,001 \pm 0,0004$ & $0,001 \pm 0,0005$ & $0,001 \pm 0,0006$ \\
\hline $\mathrm{Sm}$ & $\overline{0,001-0,9}$ & $\overline{0,0005-0,01}$ & $\overline{0,001-0,006}$ & $\overline{0,001-0,007}$ \\
\hline$F_{\mu}$ & $0,02 \pm 0,01$ & $0,003 \pm 0,0005$ & $0,001 \pm 0,0007$ & $0,001 \pm 0,0003$ \\
\hline Eu & $\overline{0,001-0,2}$ & $\overline{0,0001-0,01}$ & $\overline{0,001-0,01}$ & $\overline{0,001-0,003}$ \\
\hline$T h$ & $0,01 \pm 0,006$ & $0,01 \pm 0,001$ & $0,002 \pm 0,0008$ & $0,01 \pm 0,003$ \\
\hline$T b$ & $\overline{0,001-0,1}$ & $\overline{0,0002-0,03}$ & $\overline{0,001-0,008}$ & $\overline{0,001-0,03}$ \\
\hline$Y h$ & $0,01 \pm 0,003$ & $0,03 \pm 0,01$ & $0,02 \pm 0,003$ & $0,01 \pm 0,004$ \\
\hline$Y b$ & $\overline{0,0004-0,03}$ & $\overline{0,0003-0,3}$ & $\overline{0,0004-0,03}$ & $\overline{0,0003-0,03}$ \\
\hline & & $* 0,001 \pm 0,0001$ & $0,001 \pm 0,0001$ & $0,0004 \pm 0,0003$ \\
\hline$L u$ & Н.П.о. & $0,001-0,003$ & $\overline{0,0003-0,002}$ & $\overline{0,0002-0,001}$ \\
\hline & $0,003 \pm 0,001$ & $0,002 \pm 0,002$ & $0,002 \pm 0,001$ & $0,004 \pm 0,002$ \\
\hline$H f$ & $\overline{0,001-0,02}$ & $\overline{0,001-0,04}$ & $\overline{0,001-0,01}$ & $\overline{0,001-0,02}$ \\
\hline$T_{\Omega}$ & $* 0,004 \pm 0,001$ & $* 0,004 \pm 0,001$ & & $0,001 \pm 0,0004$ \\
\hline Ia & $\overline{0,0001-0,01}$ & $\overline{0,001-0,01}$ & Н.П.О. & $\overline{0,0001-0,01}$ \\
\hline & $0,001 \pm 0,0002$ & $0,001 \pm 0,0001$ & $* 0,01 \pm 0,003$ & $0,0004 \pm 0,00004$ \\
\hline$A u$ & $\overline{0,0002-0,004}$ & $\overline{0,0003-0,003}$ & $\overline{0,0004-0,02}$ & $\overline{0,0002-0,001}$ \\
\hline & $0,04 \pm 0,03$ & $0,01 \pm 0,001$ & $0,01 \pm 0,0002$ & $0,006 \pm 0,002$ \\
\hline Ih & $\overline{0,001-0,4}$ & $\overline{0,0001-0,02}$ & $\overline{0,003-0,01}$ & $\overline{0,0003-0,02}$ \\
\hline$U$ & $0,02 \pm 0,01$ & $0,02 \pm 0,02$ & $* 0,1 \pm 0,02$ & $0,01 \pm 0,007$ \\
\hline$U$ & $\overline{0,001-0,1}$ & $\overline{0,001-0,4}$ & $\overline{0,01-0,2}$ & $\overline{0,001-0,1}$ \\
\hline
\end{tabular}

Примечание. Н.n.о. - ниже предела обнаружения; * - элементы со значимыми уровнями различия по сравнению с его содержанием в крови жителей минимальной 3.P.P., p < 0,05 (по результатам теста Манна-Уитни). 
Джамбаев М.Т., Барановская Н.В., Липихина А.В.

Из таблицы видно, что значимые уровни различия по сравнению с содержанием в крови жителей минимальной зоны риска имели: в чрезвычайной зоне радиационного риска: $\mathrm{Na}, \mathrm{Cr}, \mathrm{Fe}, \mathrm{Co}, \mathrm{Br}, \mathrm{La}, \mathrm{Ce}$, $\mathrm{Nd}, \mathrm{Sm}, \mathrm{Ta}$; в максимальной зоне радиационного риска: $\mathrm{Na}, \mathrm{Fe}, \mathrm{Br}, \mathrm{Cs}, \mathrm{Ce}, \mathrm{Lu}, \mathrm{Ta}$; в повышенной зоне радиационного риска: $\mathrm{Na}, \mathrm{Ca}, \mathrm{Co}, \mathrm{Br}, \mathrm{Au}, \mathrm{U}$. Общей характерностью для всех рассматриваемых зон Р.Р. по сравнению с минимальной зоной Р.Р. является сравнительно высокая концентрация $\mathrm{Na}$ и $\mathrm{Br}$. Следует отметить, что концентрации $\mathrm{Cr}, \mathrm{Co}, \mathrm{Cs}, \mathrm{La}, \mathrm{Ce}, \mathrm{Sm}$ в крови жителей чрезвычайной зоны Р.Р. выше по сравнению с кровью жителей минимальной зоны Р.P. на несколько порядков.

В дальнейшем сравнение элементного состава крови было проведено по аддитивному показателю сумме концентраций всех элементов, определяемых методом ИНАА. Применение такого рода показателя позволяет исключить некоторые индивидуальные факторы накопления химических элементов, позволяя тем самым увидеть территориальные особенности накопления химических элементов в организме человека [20]. Так, было установлено, что сумма концентраций 28 химических элементов прямо пропорциональна коллективным дозам облучения населения сравниваемых территорий (рис. 3). Следует отметить, что суммы концентраций химических элементов, накапливаемых в крови населения чрезвычайной зоны, в 1,6 раз превышает этот показатель для населения минимальной зоны радиационного риска.

таблица 3 - Биогеохимические ряды накопления химических элементов в крови жителей территорий с различной дозовой нагрузкой

\begin{tabular}{|c|c|c|}
\hline \multirow{3}{*}{$\begin{array}{l}\text { Чрезвычайная } \\
\text { зона }\end{array}$} & Бодене & 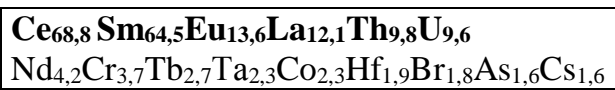 \\
\hline & Долонь & $\mathbf{C e}_{11,0} \mathbf{S m}_{10,1} \mathrm{Nd}_{2,6} \mathrm{Cr}_{2,5} \mathrm{La}_{2,0} \mathrm{Cs}_{1,8} \mathrm{Ta}_{1,8} \mathrm{Eu}_{1,7}$ \\
\hline & Саржал & $\mathrm{Co}_{2,3} \mathrm{Ta}_{2,0} \mathrm{Ba}_{2,0} \mathrm{Ce}_{1,9} \mathrm{Sb}_{1,8} \mathrm{Nd}_{1,7}$ \\
\hline \multirow{4}{*}{$\begin{array}{l}\text { Максимальная } \\
\text { зона }\end{array}$} & Канонерка & $\mathrm{Ta}_{2,9} \mathrm{Nd}_{2,0} \mathrm{Cs}_{1,7} \mathrm{Br}_{1,6}$ \\
\hline & Новопокровка & $\mathrm{Lu}_{2,2} \mathrm{Ba}_{1,7} \mathrm{Sc}_{1,5} \mathrm{Eu}_{1,5} \mathrm{Yb}_{1,5}$ \\
\hline & Медеу & $\mathrm{Tb}_{3,8} \mathrm{Ta}_{3,2} \mathrm{Nd}_{2,0} \mathrm{Co}_{1,6}$ \\
\hline & Караул & $\mathrm{Co}_{2,6} \mathrm{Br}_{1,7}$ \\
\hline $\begin{array}{l}\text { Повышенная } \\
\text { зона }\end{array}$ & Зенковка & $\mathbf{U}_{\mathbf{1 0}, 1} \mathrm{Ca}_{2,5} \mathrm{As}_{2,3} \mathrm{Sr}_{2,3} \mathrm{Au}_{2,2} \mathrm{Co}_{1,7} \mathrm{~Tb}_{1,5}$ \\
\hline $\begin{array}{l}\text { Минимальная } \\
\text { зона }\end{array}$ & Кокпекты & $\mathrm{Yb}_{1,4} \mathrm{Ag}_{1,3} \mathrm{Hf}_{1,2} \mathrm{Fe}_{1,1} \mathrm{Rb}_{1,1}$ \\
\hline
\end{tabular}

\section{Заключение}

Таким образом, были выявлены различия концентраций химических элементов в крови населения, проживающего на территориях с различной дозовой нагрузкой, формировавшейся в результате деятельности бывшего Семипалатинского испытательного ядерного полигона. Так, по сравнению с минимальной зоной Р.Р. значимое различие имели концентрации $\mathrm{Na}, \mathrm{Cr}, \mathrm{Fe}, \mathrm{Co}, \mathrm{Br}, \mathrm{La}, \mathrm{Ce}, \mathrm{Nd}, \mathrm{Sm}$ в чрезвычайной зоне P.P.; $\mathrm{Na}, \mathrm{Fe}, \mathrm{Br}, \mathrm{Cs}, \mathrm{Ce}, \mathrm{Lu}$, Та в максимальной зоне P.P.; $\mathrm{Na}, \mathrm{Ca}, \mathrm{Co}, \mathrm{Br}, \mathrm{Au}, \mathrm{U}$ в повышенной зоне радиационного риска.

Суммарные показатели накопления всех химических элементов, определяемых методом ИНАА, имеют прямую корреляцию с уровнями коллективных дозовых нагрузок, что показывает примени-

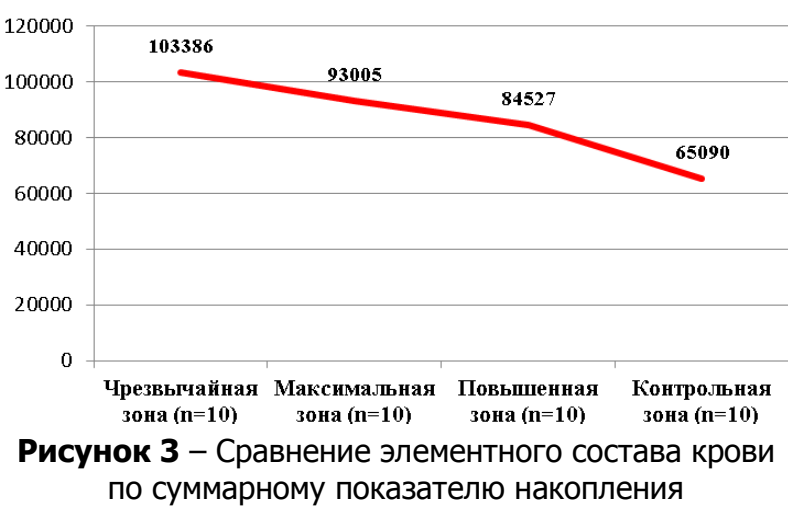

При изучении биогеохимических рядов накопления химических элементов, построенных относительно общего среднего по выборке, было установлено, что для элементного состава крови жителей чрезвычайной зоны характерен максимально широкий спектр элементов, накапливаемых $\geq 1,5$, при этом основной вклад в суммарный показатель накопления вносят такие элементы, как Ce, Sm, Eu, La и Th (табл. 3).

Биогеохимические ряды накопления химических элементов в крови жителей максимальный зоны риска не имели общую характерность.

Примечательно, что в крови жителей населенного пункта Зенковка, относящегося к повышенной зоне риска, отмечено аномальное накопление U, что, возможно, связано с индивидуальными эффективными эквивалентными дозами облучения (ЭЭД) отдельных респондентов. Данный вопрос будет рассмотрен в продолжении наших исследований. мость крови человека в оценке радиоэкологической ситуации территории.

При изучении биохимических рядов накопления химических элементов в крови населения исследуемых зон выделяется чрезвычайная зона радиационного риска, где отмечается самый широкий спектр химических элементов. При этом видно, что основной вклад в суммарный показатель накопления вносят Ce, Sm, Eu, La, а также Th и U.

В крови жителей населенного пункта Зенковка, относящегося к повышенной зоне радиационного риска, отмечается максимальная концентрация U, что требует дополнительных исследований.

\section{Список литературы:}

1. Sakaguchi A., Yamamoto M., Hoshi M., Imanaka T., Apsalikov K.N., Gusev B.I. Radiological Situation 
in the Vicinity of Semipalatinsk Nuclear Test Site: Dolon, Mostik, Cheremushka and Budene Settlements // J. of Radiation Research. 2006. № 47. P. A101-A116.

2. Bailiff I.K., Stepanenko V.F., Göksu H.Y., Jungner H., Balmukanov S.B., Balmukanov T.S., Khamidova L.G., Kisilev V.I., Kolyadao I.B., Kolizshenkov T.V., Shoikhet Y.N. The application of retrospective luminescence dosimetry in areas affected by fallout from the Semipalatinsk Nuclear Test Site: an evaluation of potential // Health Physics. 2004. № 87. P. 625-641.

3. Липихина А.В. Радиоэкологическая обстановка и оценка дозовых нагрузок от долговременного воздействия радионуклидов в районе Семипалатинского испытательного ядерного полигона: на примере Абайского района: автореф. дис. ... канд. биол. наук. Томск, 2005. $163 \mathrm{c}$.

4. Скальный А.В., Рудаков И.А. Биоэлементы в медицине. М.:Мир ОНИКС 21 век, 2004. 227 с.

5. Барановская Н.В. Геохимический состав крови человека как индикатор техногенного воздействия // Проблемы геологии и освоения недр. Труды Пятого Международного симпозиума имени академика М.А. Усова студентов, аспирантов и молодых ученых, посв. столетию горно-геологического образования в Сибири. Томск: STT, 2001. С. 492-493.

6. Куценогий К.П., Савченко Т.И., Чанкина О.В., Журавская Э.Я., Гырголькау Л.А. Элементный состав крови и волос коренных жителей Севера России с разной биогеохимической средой обитания // Химия в интересах устойчивого развития. 2010. № 18. С. 51-61.

7. Ревич Б.А. Гигиеническая оценка содержания некоторых химических элементов в биосубстратах человека // Гигиена и санитария. 1986. № 7. С. 59-62.

8. Карамова Л.М., Ларионова Т.К., Башарова Г.Р. Критерии экологической безопасности тяжелых металлов в крови человека // Медицина труда и промышленная экология. 2010. № 6. С. 21-23.

9. Жук Л.И., Хаджибаева Г.С., Кист А.А. и др. О влиянии выбросов алюминиевого комбината на элементный состав биосубстратов человека // Гигиена и санитария. 1991. № 10. С. 12-15.

10. Зайчик В.Е., Агаджанян Н.А. Некоторые методологические вопросы медицинской элементоло- гии // Вестник восстановительной медицины. 2004. T. 9, № 3. C. 19-23.

11. Iyengar G.V., Kollmer W.E., Bowen H.J.M. The elemental composition of human tissues and body fluids. Weinheim-New York: Verlag Chemie, 1978. 1311. P. 7.

12. Pasha Q., Malik S.A., Shah M.H., Statistical analysis of trace metals in the plasma of cancer patients versus controls // Journal of Hazardous Materials. 2008. № 153. P. 1215-1221.

13. Hanif S., Ilyas A., Shah M.H., Statistical Evaluation of Trace Metals, TSH and T4 in Blood Serum of Thyroid Disease Patients in Comparison with Controls // Biological Trace Element Research. 2017. № august 2017. P. 1-13.

14. Heitland P., Koster H.D., Biomonitoring of 37 trace elements in the blood samples from inhabitants of northern Germany by ICP-MS,J.Trace Element. Med. Biol. 2006. 20. P. 253-262.

15. Zhanga H., Yanb C., Yanga Z., Zhanga W., Niua Y., Li a X., Qina L., Sua Q. Alterations of serum trace elements in patients with type 2 diabetes // Journal of Trace Elements in Medicine and Biology. 2017. № 40. P. 91-96.

16. Семиошкина Н.А. Оценка радиологических последствий радиоактивного загрязнения территории Семипалатинского испытательного полигона: дис. ... канд. биол. наук. Обнинск, 2002. 104 с.

17. Закон Республики Казахстан от 18 декабря 1992 года № 1787-XII «О социальной защите граждан, пострадавших вследствие ядерных испытаний на Семипалатинском испытательном ядерном полигоне» // Ведомости Верховного Совета Республики Казахстан. 1992 г. № 23, ст. 560.

18. Будников Г.К. Определение следовых количеств веществ как проблема современной аналитической химии // Соросовский образовательный журнал. 2000. № 3. C. 45-51.

19. Nakahara H., Nagame Y., Yoshizowa Y. at oth. Trace element analysis of human blood serum by neutron activation analysis // J. of Radioan. Chem. 1979. Vol. 54, № 12. P. 183-190.

20. Игнатова Т.Н. Элементный состав организма человека и его связь с факторами среды обитания: дис. ... канд. геол.-мин. наук. Томск, 2010. 228 с.

\section{PECULIARITIES OF HUMAN'S BLOOD ELEMENTAL COMPOSITION INHABITED IN DIFFERENT RADIATION EXPOSURE}

(C) 2018

Jambayev Merey Tleykhanovich, postgraduate student

of Geology Division of Engineering School of Natural Resources

Baranovskaya Natalia Vladimirovna, doctor of biological sciences, professor of Geology Division of Engineering School of Natural Resources

National Research Tomsk Polytechnic University (Tomsk, Russian Federation)

Lipikhina Alexandra Viktorovna, candidate of biological sciences, leading researcher of Scientific Department Scientific Research Institute for Radiation Medicine and Ecology

(Semey, East Kazakhstan Region, Republic of Kazakhstan)

\footnotetext{
Abstract. The paper deals with the features of chemical elements accumulation in the blood of the population living on the territories close to the former Semipalatinsk nuclear test site. The investigated territories as a result of earlier conducted radioecological research by the legislation of the Republic of Kazakhstan are referred to different zones of radiation risk. As a control area, the settlement of Kokpekty, referring to the minimum radiation risk zone, was chosen with a radiation dose of 0,1 to $7 \mathrm{cSv}$ obtained for the entire test period. The study of the elemental composition of the blood of the population exposed to different dose irradiation on this territory has been carried out for the first time. A comparison was made of the concentrations of 28 chemical elements determined by the instrumental neutron activation analysis in the blood of the population of various radiation risk zones. The summary indicators of
} 36 Самарский научный вестник. 2018. Т. 7, № 1 (22) 
Джамбаев М.Т., Барановская Н.В., Липихина А.В.

chemical elements accumulation in human blood, characterizing the levels of established dose loads of the population, are calculated. Biogeochemical series of chemical elements accumulation in the blood of the population of the considered settlements, relative to the general average on the territory, have been built. The elements that make the main contribution to the total index of chemical elements accumulation in the blood of the population of the investigated radiation risk zones have been established. In general, it has been shown that the elemental composition of human blood can reflect the general radioecological situation of the territory.

Keywords: human blood; radiation risk zones; emergency zone of radiation risk; maximum zone of radiation risk; increased zone of radiation risk; minimal zone of radiation risk; radiation doses; concentration of elements; biogeochemical series of accumulation of elements; total accumulation of elements.

УДК 581.9 (476)

Статья поступила в редакцию 08.07.2017

\section{СОСТОЯНИЕ ПОПУЛЯЦИЙ ASTRAGALUS CORNUTUS PALL. В САМАРСКОЙ ОБЛАСТИ} (C) 2018

Ильина Валентина Николаевна, кандидат биологических наук, доцент кафедры биологии, экологии и методики обучения

Самарский государственный соииально-педагогический университет (г. Самара, Российская Федераџия)

Аннотация. В данной статье рассматриваются особенности демографической структуры природных популяций редкого представителя степной флоры астрагала рогоплодного (Astragalus cornutus Pall. (Fabaceae)). Редкость вида обусловливает необходимость его включения в Красные книги Российской Федерации и некоторых степных регионов. В Самарской области популяции вида требуют дополнительной охраны в связи с особенностями биологии и экологии, значительной антропогенной нагрузкой на сообщества, а также сокращением числа местообитаний. Нами изучены особенности структуры популяций в Самарском Заволжье. Всего обследовано 84 ценопопуляции, выявлены тенденции изменения численности, особенности демографической и пространственной структуры. На структуру популяций астрагала рогоплодного влияют экологофитоценотические условия среды и антропогенные факторы. Замещение и восстановление особей в популяциях A. cornutus идет замедленными темпами. Онтогенетическая структура популяций имеет флуктуационную динамику. Оценка исследованных географических популяций по критерию эффективности Л.А. Животовского показала, что все они являются зрелыми. Конкретные ценопопуляции A. cornutus стареющие (5\%) и старые (8\%). Средняя плотность особей составляет около 3 шт./м². Средняя эффективная плотность состав-

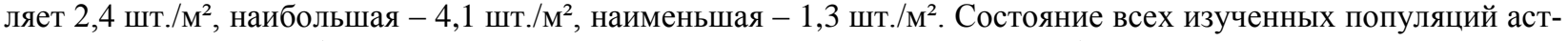
рагала рогоплодного (даже находящихся в удовлетворительном состоянии) на территории Самарской области вызывает опасение. Популяции вида в области нуждаются в дополнительных мерах охраны.

Ключевые слова: Astragalus cornutus; Fabaceae; ценопопуляция; онтогенетическая структура; базовый онтогенетический спектр; индекс замещения; индекс восстановления; индекс старения; критерий эффективности; зрелая популяция; редкий вид; Самарская область; Красная книга; памятник природы; антропогенный фактор; растительное сообщество; степи.

\section{Введение}

Популяционно-онтогенетические исследования редких видов растений локальных флор часто используются при проведении комплексного мониторинга природных комплексов в различных целях, в том числе при определении современного состояния, выявлении структуры и динамики растительных сообществ. Данные методики актуальны при оценке запасов лекарственного сырья, определении потенциального и реального возобновления растительных ресурсов в природных условиях, эффективности интродукции и реинтродукции и решении разнообразных задач при сохранении биологического разнообразия [1-8]. В бассейне Средней Волги тщательного изучения требует значительное число представителей. Особую позицию занимают виды-ксерофиты как наиболее уязвимые в связи с антропогенной трансформацией и уничтожением степных местообитаний [5-9].

Цель нашего исследования заключается в определении состояния популяций редкого в Самарской области Astragalus cornutus Pall. (Fabaceae).

объект и методика исследования

Астрагал рогоплодный (Astragalus cornutus Pall.) включен в первое издание Красной книги Самарской области (далее СО) со статусом редкости 4/Г - редкий вид со стабильной численностью $[9 ; 10]$. В СО его популяции находятся на северной границе ареала. Исследования популяций проводились нами в 2008-2014 гг. с использованием стандартных методик [11-19]. Определены онтогенетический состав популяций, основные демографические показатели (индексы восстановления, замещения и старения), типы популяций по критерию «дельта-омега» Л.А. Животовского [17], основные эколого-фитоценотические параметры местообитаний, дана оценка современного состояния популяций.

Территория исследования охватывает Самарское Заволжье, в том числе популяции изучены на территории памятников природы регионального значения «Гора Копейка» (Похвистневский район), «Верховой овраг», «Чубовская луговая степь» (Кинельский), «Гора Красная», «Гора Лысая» (Красноярский), «Гора Зеленая» (Елховский), «Мулин дол» (урочище Верхние Скрипали) (Большечерниговский район $\mathrm{CO}$ ). Данные территории характеризуются высокой концентрацией редких и эндемичных видов растений, занесенных в федеральную и региональную Красные книги [10; 20].

\section{Результаты исследования и их обсуждение}

Некоторые результаты исследований популяций A. cornutus опубликованы нами ранее [6]. В обследо- 